\title{
ANALISIS KEWENANGAN POLRI DALAM MELAKUKAN PENYIDIKAN PENANGKAPAN TINDAK PIDANA KORUPSI (STUDI DI KABUPATEN NGANJUK)
}

\author{
Zainal Arifin ${ }^{1}$, Hary Masrukin ${ }^{2}$ \\ 1. Universitas Islam Kadiri, Kediri \\ 2. Advokat dan Konsultan Hukum
}

\begin{abstract}
ABSTRAK
Tugas Pokok Kepolisian Negara Republik Indonesia Dalam Undang-Undang Republik Indonesia Nomer 2 tabun 2002 Tentang Kepolisian Republik Indonesia Pasal 13 dan pasal 14 adalah memelihara keamanan dan ketertiban masyarakat, menegakkan hukum, memberikan perlindungan, pengayoman dan pelayanan kepada masyarakat, melaksanakan pengaturan, penjagaan, pengawalan, dan patroli terhadap. masyarakat dan pemerintah sesuai kebutuhan, menyelenggarakan segala kegiatan dalam menjamin keamanan, ketertiban, dan kelancaran lalu lintas di jalan, membina masyarakat untuk meningkatkan partisipasi masyarakat, kesadaran hukum masyarakat serta ketaatan warga masyarakat terhadap hukum dan peraturan perundang-undangan, turut serta dalam pembinaan hukum nasional dan memelihara ketertiban dan menjamin keamanan umum, melakukan koordinasi, pengawasan, dan pembinaan teknis terhadap kepolisian khusus, penyidik pegawai negeri sipil, dan bentuk-bentuk pengamanan swakarsa, melakukan penyelidikan dan penyidikan terhadap semua tindak pidana sesuai dengan hukum acara pidana dan peraturan perundang-undangan lainnya, menyelenggarakan identifikasi kepolisian, kedokteran kepolisian, laboratorium forensik dan psikologi kepolisian untuk kepentingan tugas kepolisian, melindungi keselamatan jiwa raga, harta benda, masyarakat dan lingkungan hidup dari gangguan ketertiban dan/atau bencana termasuk memberikan bantuan dan pertolongan dengan menjunjung tinggi hak asasi manusia, melayani kepentingan warga masyarakat untuk sementara sebelum ditangani oleh instansi dan/atau pihak yang berwenang, memberikan pelayanan kepada masyarakat sesuai dengan kepentingannya dalam lingkup tugas kepolisian; serta melaksanakan tugas lain sesuai dengan peraturan perundangundangan.

Rumusan masalah pada Tesis ini adalah (1) Apa Yang Menjadi Dasar Hukum POLRI Dalam Melakukan Penyidikan Penangkapan Tindak Pidana Korupsi? (2) Bagaimana Proses POLRI Dalam Melakukan Penyidikan Penangkapan Tindak Pidana Korupsi? (3) Apa Kendala POLRI Dalam Melakukan Penyidikan Penangkapan Tindak Pidana Korupsi

Jenis penelitian ini adalah Metode pendekatan yang dilakukan menggunakan metode pendekatan Yuridis empiris. Metode ini mempunyai tujuan untuk menilai dan melihat pelaksanaan kinerja seseorang dan penelitian kepustakaan serta penelitian lapangan, penelitian ini bersifat kualitatif untuk melihat secara langsung gambaran yang terjadi di masyarakat.

Hasil penelitian ini adalah Dasar hukum POLRI dalam Melakukan Penyelidikan Penangkapan Tindak Pidana Korupsi yaitu sudah sesuai dengan aturan Perundang-undangan, memakai Standar Operasional Prosedur, Surat Perintah Penangkapan, Surat Pemberitahuan dimulainya penyidikan, surat perintah tugas penyelidik dan Penyidik. Jadi Setiap POLRI / Petugas Dalam menjalankan kewajiban dan wewenang nya selalu berpedoman dengan aturan atau perundang-undangan yang berlaku. Apabila ada petugas penyelidik ataupun Penyidik pada waktu menjalankan tugasnya tidak sesuai aturan atau SOP POLRI maka perlu mendapatakan teguran dari atasan atau Provos bahkan kritik dari masyarakat.

Kata Kunci : Kewenangan POLRI, Penyelidikan-Penyidikan-Penangkapan Dan Tindak Pidana Korupsi
\end{abstract}

\section{A. PENDAHULUAN}

Negara Indonesia adalah Negara hukum, sebagaimana diamanatkan di ketentuan pasal 1 ayat (3) Undang-Undang Dasar Negara Republik Indonesia. Aturan tersebut harus di taati oleh masyarakat Indonesia, sebagai warga negara yang baik kita harus patuh dan taat kepada hukum yang ada. Dalam rangka mencapai tujuan Nasional yang ditandai oleh terjaminya keamanan, ketertiban dan tegaknya 
hukum serta menjaga Kesatuan Republik Indonesia, perlu penegak hukum yaitu Tentara Nasional Indonesia dan Polisi Republik Indonesia

Permasalahan korupsi di Indonesia sudah memprihatinkan banyak pihak, karena tindak pidana korupsi di Indonesia sangat kompleks. Korupsi telah merambat di lembaga, legislatif, eksekutif, dan yudikatif. Bahwa tidak jarang lagi korupsi itu dikategorikan kejahatan luar biasa (extraordinary crime), jadi pemberantasan korupsi harus dilakukan dengan cara yang luar biasa juga (extraordinary enforcement) dikarenakan masalah korupsi berakar dalam kehidupan kita berbangsa dan bernegara.

Sistem peradilan pidana (Criminal Justice System) sebagai suatu sistem dalam masyarakat untuk menanggulangi masalah kejahatan dimaknai sebagai upaya untuk mengendalikan atau membatasi kejahatan agar berada dalam batas-batas toleransi masyarakat. Komponenkomponen yang berkerja dalam sistem ini meliputi Kepolisian, Kejaksaan, Kpk, pengadilan dan lembaga pemasyarakatan. Empat komponen ini diharapkan dapat bekerjasama sehingga menghasilkan suatu keterpaduan yang kita kenal dengan integrated criminal justice system.

Kepolisian Negara Republik Indonesia adalah pegawai negeri pada kepolisian Negara Republik Indonesia, Pejabat kepolisian Negara Republik Indonesia adalah anggota Kepolisian Negara Repulik Indonesia yang berdasarkan undang-undang memiliki wewenang umum Kepolisian. Fungsi kepolisian salah satu fungsi pemerintahan negara di bidang pemeliharaan keamanan dan ketertiban masyarakat, penegakan hukum, perlindungan, pengayoman dan pelayanan kepada masyarakat, tujuan Kepolisian untuk mewujudkan keamanan dalam negeri yang meliputi terpeliharanya keamanan dan ketertiban masyarakat, tertib dan tegaknya hukum, terselenggaranya perlindungan, pengayoman, dan pelayanan kepada masyarakat, serta terbinanya ketenteraman masyarakat dengan menjunjung tinggi hak asasi manusia

Dalam Kitab Undang-Undang Hukum Acara Pidana, kewenangan penyidikan jatuh ketangan Kepolisian Republik Indonesia itu sesuai Pasal 6 Kitab Undang-Undang Hukum Acara Piodana menyebutkan penyidik adalah Pejabat Polisi Negara Republik Indonesia dan Pejabat Pegawai Negeri Sipil tertentu yang diberi wewenang khusus oleh UndangUndang,syarat kepangkatan pejabat sebagaimana dimaksud dalam ayat (1) akan diatur dalam perarturan pemerintah, ini berarti bahwa kepolisian adalah penyidik tunggal didalam Kitab Undang Hukum Aacara Pidana. ${ }^{1}$ Salah satu proses yang penting dalam penyelesaian tindak pidana korupsi adalah proses penyidikan. Kewenangan penyidikan dalam tindak pidana korupsi menurut peraturan perundang-undangan yang berlaku selalu dikaitkan dengan aparat penegak hukum Kepolisian yaitu di kepala satuan resort criminal di unit tipikor (tindak pidana korupsi). Karena tugas inti dari kepolisian republik Indonesia adalah mengayomi, melindungi serta memberikan rasa kemanan juga ketertiban kepada masyarakat. Penyidikan yang dimaksud yaitu tentang penangkapan yang dilakukan aparat penegak hukum yaitu POLRI, Penangkapan sendiri memiliki arti Penangkapan adalah suatu tindakan penyidik berupa pengekangan sementara waktu kebebasan tersangka atau terdakwa apabila terdapat cukup bukti guna kepentingan penyidikan atau penuntutan dan atau peradilan dalam hal serta menurut cara yang diatur dalam undang-undang ini dan ada juga lain dari penangkapan yaitu tangkap tangan yaitu Tertangkap Tangan adalah tertangkapnya seorang pada waktu sedang melakukan tindak pidana, atau dengan segera sesudah beberapa saat tindak pidana itu dilakukan, atau sesaat kemudian diserukan oleh khalayak ramai sebagai orang yang melakukannya atau pabila sesaat kemudian padanya ditemukan benda yang diduga keras telah di pergunakan untuk melakukan tindak pidana itu yang menunjukkan bahwa ia adalah pelakunya atau turut melakukan atau membantu melakukan tindak pidana itu.

Penangkapan mempunyai syarat-syarat yaitu adanya dugaan keras melakukan tindak pidana berdasarkan bukti cukup, dengan surat perintah menangkap dari pejabat yang berwenang, surat penangkapan memuat identitas, alasan, uraian singkat tindak pidana, surat tugas dari pejabat yang berwenang yaitu dari kasatreskrim atau kanit tipikor atau penyidik, pelaksana penangkapan adalah Polisi Republik Indonesia, cara-cara dan Proses

\footnotetext{
${ }^{1}$ Karjadi \& soesilo, Kitab Undang-Undang Hukum Acara Pidana (nomer 8 tabun 1981), 1986 , Bogor: PT Karya nusantara, Pasal 6, h 15
} 
Penyelidikan-Penyidikan-Penangkapan dan Polisi Republik Indonesia menunjuk petugas yang mempunyai jabatan khusus yaitu penyidik serta penyidik pembantu. Maka dari itu peneliti ingin memberikan pengetahuan kepada masyarakat tentang aturan-aturan/UndangUndang yang dibuat dasar/acuan aparat penegak hukum Polisi Republik Indonesia dalam melakukan penyidikan penangkapan tindak pidana korupsi, peneliti juga memberikan pengetahuan kepada masyarakat tentang bagaimana proses penyelidikan sampai penyidikan sampai penangkapan yang dilakukan aparat penegak hukum Polisi Republik Indonesia dalam menangani tindak pidana korupsi, peneliti juga ingin menjelaskan kepada masyrakat bahwa adapun kendala-kendala polisi republik Indonesia dalam menangani penyidikan penangkapan dalam tindak pidana korupsi.

\section{Rumusan Masalah}

1. Apa Yang Menjadi Dasar Hukum Polri Dalam Melakukan Penyidikan penangkapan Tidak Pidana Korupsi?

2. Bagaimana Proses Polri dalam melakukan penyidikan penangkapan tindak pidana korupsi?

3. Apa kendala yang dialami Polri dalam melakukan penyidikan penangkapan tindak pidana korupsi?

\section{Metode Penelitian}

\section{Jenis Penelitian}

Jenis penelitian ini adalah Metode pendekatan yang dilakukan dalam melakukan penelitian ini dilakukan dengan menggunakan metode pendekatan Yuridis empiris. Metode ini mempunyai tujuan untuk menilai dan melihat pelaksanaan kinerja seseorang dan dilakukan dengan mengadakan penelitian kepustakaan serta penelitian lapangan, serta penelitian ini bersifat kualitatif untuk melihat secara lansgsung yang terjadi di masyarakat dan memberikan gambaran. Jadi pendekatan yuridis (hukum dilihat sebagai norma ats das solen), karena dalam membahas permsalahan penelitian ini menggunakan bahan-bahan hukum (baik bahan hukum yang tertulis maupun hukum yang tidak tertulis atau baik hukum primer mupun sekunder). Pendekatan empiris (hukum sebagai kenyataan social, kultural atau das sein), menganalisis permasalahan dilakukan dengan cara memadukan bahan-bahan hukum data dari sekunder dengan data primer yang diperoleh dari lapangan

\section{Lokasi Penelitian}

Studi Penelitian yang dilakukan berada di suatu tempat yaitu di Polres Nganjuk, Proses masuk POLRES untuk melakukan penelitian itu pertama surat izin penelitian dari kampus diberikan ke KBO Polres, setelah itu KBO membuat laporan/pemberitahuan ke Satuan Reskrim untuk menindak lanjuti tersebut. Kemudian satuan resort kriminal ditujukkan ke unit tindak pidana korupsi dan berada di Kantor bidang tindak pidana khusus yaitu tindak pidana korupsi serta di kantor satuan reskrim Polres Nganjuk. Peneliti bertemu penyidik tindak pidana korupsi dan bertemu kepala satuan resort kriminal serta kepala unit satuan tindak pidana korupsi. Itulah gambaran tata cara penelitian di lokasi dan peneliti juga bertemu dengan beberapa petugas/penyidik disana.

3. Sumber Bahan Hukum

a) Bahan Hukum Primer

Dalam hal ini bahan hukum primer merupakan bahan hukum bersifat autoritatif artinya mempunyai otoritas. Bahan-bahan hukum terdiri Undang-Undang Dasar 1945, perundang-undangan, catatan-catatan resmi atau risalah dalam pembuatan Perundang-undangan dan putusan-putusan hakim. ${ }^{2}$. Dalam hal ini peneliti mengacu pada bahan hukum Peraturan kapolri (Perkap), Undang-undang tentang Kepolisian Negara Republik Indonesia, Peraturan Pemerintah Republik Indonesia, Undang-Undang Tentang hukum acara pidana, Undang-Undang Penyelenggaraan Negara Yang Bersih Dan Bebas Dari Korupsi, Kolusi Dan Nepotisme, Undang-Undang Pemberantasan Korupsi, Undang-Undang Komisi Pemberantasan Korupsi, Undang-Undang Dasar Negara Republik Indonesia tahun 1945, Peraturan Kapolri tentang Kode Etik Profesi POLRI dan Standart Polri dalam Operasional Pelaksanaan (SOP).

b) Bahan Hukum Sekunder

Semua publikasi tentang hukum meliputi buku-buku teks hukum, kamus-kamus hukum, komentar-komentar atas putusan pengadilan, artikel tentang hukum dan jurnal tentang hukum. Maka peneliti memakai bahan hukum sekunder yaitu buku-buku hukum sebagai materi, studi kepustakaan dan buku penelitian hukum.

\footnotetext{
${ }^{2}$ Ibid, hal 181
} 


\section{c) Data Tersier}

Bahan hukum tersier adalah bahan hukum yang mendukung bahan hukum primer dan bahan hukum sekunder dengan memberikan pemahaman dan pengertian atas bahan hukum lainya. Bahan hukum yang dipergunakan oleh penulis adalah Kamus Besar Bahasa Indonesia dan kamus hukum serta buku panduan penulisan penelitian serta buku-buku yang lainya.

4. Teknik Pengumpulan Bahan Hukum

a) Observasi

Observasi adalah teknik pengumpulan data yang mempunyai ciri spesifik bila dibandingkan dengan teknik wawancara dan kuesioner, hal ini dikarenakan observasi ruang geraknya tidak hanya berlingkup pada manusia sebagai objek penelitian akan tetapi juga menyangkut objek-objek alam atau objek sosial yang dijadikan pusat penelitian wawancara

Metode pengamatan yang dilakukan oleh peneliti adalah pengamatan kepada manusia sebagai objek penelitian yaitu Kepala Unit Pidana khusus korupsi di Polres Nganjuk dan juga objek sosial objek kajian nya adalah hukum positif yaitu Undang-Undang Tentang Polisi Republik Indonesia, Peraturan kapolri: manajemen penyidikan, Standart Operasioanal Pelaksanaan POLRI (SOP), Undang-Undang tentang pemberantasan tindak pidana korupsi, Undang-Undang Tentang Komisi pemberantasan korupsi, Undang-Undang Penyelenggaraan Negara Yang Bersih Dan Bebas Dari Korupsi, Kolusi Dan Nepotisme, Undang-Undang tentang Hukum Acara Pidana, Dan aturan aturan yang mengenai kewenangan Penyidikan tentang tindak pidana korupsi.

b) Wawancara

Pengumpulan data kedua yang dilakukan oleh peneliti, yakni dengan memanfaatkan metode wawancara. wawancara adalah percakapan dengan maksud tertentu, yang dilakukan oleh dua orang yakni pewawancara (yang mengajukan pertanyaan) dan terwawancara (pihak yang diberi pertanyaan dan menjawab pertanyaan) ${ }^{3}$. Penulis menggunakan metode wawancara dengan Kepala Unit Tindak Pidana Korupsi di Polres Nganjuk serta menggunakan analisa data Primer yaitu mengacu pada bahan hukum Peraturan kapolri (Perkap), Undangundang tentang Kepolisian Negara Republik

\footnotetext{
${ }^{3}$ Moleong, Lexy J. Metode Penelitian Kualitatif. Bandung. PT Remaja Indonesia. 2010. h 186
}

Indonesia, Peraturan Pemerintah Republik Indonesia, Undang-Undang Hukum Aacara Pidana, Undang-Undang Komisi Pemberantasan Korupsi, Undang-Undang Penyelenggaraan Negara Yang Bersih Dan Bebas Dari Korupsi, Kolusi Dan Nepotisme, Undang-Undang Pemberantasan Korupsi dan Bahan hukum sekunder yaitu Semua publikasi tentang hukum meliputi buku-buku teks hukum, kamus-kamus hukum, komentarkomentar atas putusan pengadilan, artikel tentang hukum dan jurnal tentang hukum. Maka penulis memakai bahan hukum sekunder yaitu buku-buku hukum sebagai materi, study keputakaan dan buku penelitian hukum

c) Dokumentasi

Metode dokumentasi digunakan oleh peneliti untuk melengkapi data yang telah didapatkan melalui wawancara ataupun metode pengumpulan data lainnya, hal ini diharapkan dapat memenuhi dan melengkapi data penelitian hingga menjadi data yang valid. Dokumentasi adalah catatan peristiwa yang sudah berlalu, dapat berupa gambar, karya-karya monumental (memberikan kesan peringatan sesuatu yang penting). Peneliti ada dokumentasi yang secara empiris mencari data di lapangan yaitu foto dengan kepala Unit tipikor polres nganjuk, foto tentang bahan yang mengandung kinerja perkara tipikor

\section{B. HASIL PENELITIAN}

Hasil penelitian ini adalah Dasar hukum POLRI dalam Melakukan Penyelidikan Penangkapan Tindak Pidana Korupsi yaitu sudah sesuai dengan aturan Perundangundangan, memakai Standar Operasional Prosedur, Surat Perintah Penangkapan, Surat Pemberitahuan dimulainya penyidikan, surat perintah tugas penyelidik dan Penyidik. Jadi Setiap POLRI / Petugas Dalam menjalankan kewajiban dan wewenang nya selalu berpedoman dengan aturan atau perundangundangan yang berlaku. Apabila ada petugas penyelidik ataupun Penyidik pada waktu menjalankan tugasnya tidak sesuai aturan atau SOP POLRI maka perlu mendapatakan teguran dari atasan atau Provos bahkan kritik dari masyarakat.

'Dasar hukum POLRI Dalam melakukan penyidikan Penangkapan Tindak Pidana Korupsi yaitu Undang-Undang Dasar Negara Republik Indonesia 1945, UndangUndang Republik Indonesia Nomor 2 Tahun 
2002 Tentang Kepolisian Republik Indonesia, Undang-Undang Republik Indonesia Nomor 8 Tahun 1981 Hukum Acara Pidana, UndangUndang Republik Indonesia Nomor 28 Tahun 1999 Penyelenggaraan Negara Yang Bersih Dan Bebas Dari Korupsi, Kolusi Dan Nepotisme, Undang-Undang Republik Indonesia Nomor 20 Tahun 2001 Pemberantasan Tindak Pidana Korupsi, Undang-Undang Republik Indonesia Nomer 15 tahun 2006 Tentang Badan Pemeriksa Keuangan, Undang-Undang Republik Indonesia Nomer 36 Tahun 1999 Tentang Telekomunikasi, Peraturan Pemerintah Negara Republik Indonesia 52 Tahun 2000 Penyelenggaraan Telekomunikasi, Peraturan Pemerintah Negara Republik Indonesia Nomer 12 Tahun 2017 Tentang Pembinaan Dan Pengawasan Penyelenggaraan Pemerintah Daerah, Peraturan Pemerintah Negara Republik Indonesia Nomer 18 Tahun 2016 Tentang Perangkat Daerah, Peraturan Kepala Kepolisian Negara Republik Indonesia Nomer 14 Tahun 2012 Tentang Manajemen Penyidikan Kepolisian Republik Indonesia, Peraturan Kepala Kepolisian Negara Republik Indonesia Nomer 16 Tahun 2010 Tentang Tata Cara Pelayanan Informasi Publik Di Lingkungan Kepolisian Negara Republik Indonesia, Peraturan Presiden Republik Indonesia Nomer 192 Tahun 2014 Tentang Badan Pengawasan Keuangan Dan Pembangunan.

Proses POLRI Dalam Melakukan Penyidikan Penangkapan Tindak Pidana Korupsi yaitu Proses awal mulai pelaporan sampai Penyelidikan, penyidikan dan penangkapan. Berdasarkan hasil wawancara dengan Kanit tipikor dan kasat reskrim, ada tahap dan poin-poin nya yaitu Penerimaan informasi atau Laporan, Penelitian Laporan, Penyelidikan, Administrasi Penyelidikan, Skema Penyelidikan, Administrasi Penyelidikan, Penindakan, Penangkapan dan hal-hal yang perlu di perhatikan Untuk mengetahui unsur memperkaya diri sendiri / orang lain maka perlu adanya penelusuran tentang aliran dana dan Aset/ harta kekayaan yang diperoleh hasil kejahatan, Untuk memanggil kepala daerah/wakil kepala daerah harus sesuai dengan tata cara yang diatur Undang-Undang.

Kendala Kendala yang dialami Polisi (Penyidik, Kanit Tipikor) yaitu Permintaan auditor ke BPKP (Badan Pengawas Keuangan dan Pembangunan) dan BPK (Badan Pemeriksa Keuangan) hasilnya terlalu lama sehingga kasus nya belum bisa terselesaikan, Dalam Menentukan tersangka itu proses yang panjang dan membutuhkan kerja sama dengan berbagai pihak yaitu Inspektorat daerah, Dalam menentukan tersangka tindak pidana korupsi itu membutuhkan proses serta audit dari berbagai lembaga dengan menentukan kerugian negara, Dalam mencari alat bukti berupa Informasi Tekonologi (IT) harus berkordinasi dengan Lab Forensik di Polda Jatim sehingga waktunya lama berdampak dalam waktu penyidikan, dalam memanggil saksi ahli di persidangan yaitu BPK (Badan Pemeriksa Keuangan) dan BPKP (Badan Pengawas Keuangan dan Pembangunan) harus bergantian dan menunggu karena personil di provinsi sedikit.

Kendala dari para petugas (penyelidik, penyidik dan Kanit tipikor) kurangnya personil/pegawai (BPK dan BPKP) di provinsi sehingga mengganggu kinerja dalam bekerja, harus terus menerus berkordinasi dengan lembaga-lembaga terkait yaitu (BPK, BPKP, Inspektorat daerah, DPRD dan kejaksaan) seta berkomunikasi sinergi dengan (lembaga swadaya masyarakat, lembaga anti korupsi, masyarakat) agar terselesaikan masalah korupsi dan membangun kabupaten Nganjuk bebas Korupsi.

Kendala dan solusi yang lain adalah dalam memanggil kepala atau wakil daerah harus disesuaikan menurut aturan aturan dan tata cara pemanggilan yang sesuai dengan aturanya adalah (Pasal 36 Undang-Undang Republik Indonesia No. 32 Th 2004 dan tata caranya). Solusi untuk mengatasi kendalakendala penyelidik dan penyidik dalam memberantas tindak pidana korupsi yaitu apabila meminta audit ke BPKP, BPK dengan menggunakan surat permohonan serta langsung datang kantor untuk menanyakan proses nya audit, sehingga proses audit jelas dan tranparan prosesnya, apabila BPKP dan BPK tetep lama proses auditnya bisa meminta bantuan Inspektorat daerah untuk membantu audit kasusnya.

\section{KESIMPULAN}

Sudah sesuai dengan aturan Perundangundangan yaitu memakai Dasar hukum POLRI dalam Melakukan Penyelidikan Penangkapan Tindak Pidana Korupsi yaitu sudah sesuai dengan aturan Perundang-undangan, memakai Standar Operasional Prosedur, Surat Perintah Penangkapan, Surat Pemberitahuan dimulainya 
penyidikan, surat perintah tugas penyelidik dan Penyidik. Jadi Setiap POLRI / Petugas Dalam menjalankan kewajiban dan wewenang nya selalu berpedoman dengan aturan atau perundang-undangan yang berlaku. Apabila ada petugas penyelidik ataupun Penyidik pada waktu menjalankan tugasnya tidak sesuai aturan atau SOP POLRI maka perlu mendapatakan teguran dari atasan atau Provos bahkan kritik dari masyarakat.

Untuk Memberikan Informasi mengenai kegiatan POLRI, Aturan-aturan yang berkaitan dengan POLRI ataupun dengan hukum, ada petugas tersendiri untuk mensosialisasikan aturan-aturan tentang hukum dan POLRI. Bidang humas (hubungan masyarakat) Dan petugas yang lainya. Dasar hukumnya adalah di Perkap nomer 16 tahun 2010 tentang tata cara pelayanan informasi publik di lingkungan Kepolisian republik Indonesia. Petugas memakai media elektronik seperti Hanphone, Sosial media: Facebook, Twitter, Path, Line, Whatsapp, Koran, Radio, Majalah. Itulah kesimpulan kesimpulan yang yang di tulis peneliti dan apabila membutuhkan dasar-sadar hukum nya bisa dilihat di bab 2 dan bab 3 yang lebih detail.

Dasar hukum POLRI Dalam melakukan penyidikan Penangkapan Tindak Pidana Korupsi yaitu Undang-Undang Dasar Negara Republik Indonesia 1945, UndangUndang Republik Indonesia Nomor 2 Tahun 2002 Tentang Kepolisian Republik Indonesia, Undang-Undang Republik Indonesia Nomor 8 Tahun 1981 Hukum Acara Pidana, UndangUndang Republik Indonesia Nomor 28 Tahun 1999 Penyelenggaraan Negara Yang Bersih Dan Bebas Dari Korupsi, Kolusi Dan Nepotisme, Undang-Undang Republik Indonesia Nomor 20 Tahun 2001 Pemberantasan Tindak Pidana Korupsi, Undang-Undang Republik Indonesia Nomer 15 tahun 2006 Tentang Badan Pemeriksa Keuangan, Undang-Undang Republik Indonesia Nomer 36 Tahun 1999 Tentang Telekomunikasi, Peraturan Pemerintah Negara Republik Indonesia 52 Tahun 2000 Penyelenggaraan Telekomunikasi, Peraturan Pemerintah Negara Republik Indonesia Nomer 12 Tahun 2017 Tentang Pembinaan Dan Pengawasan Penyelenggaraan Pemerintah Daerah, Peraturan Pemerintah Negara Republik Indonesia Nomer 18 Tahun 2016 Tentang Perangkat Daerah, Peraturan Kepala Kepolisian Negara Republik Indonesia Nomer 14 Tahun
2012 Tentang Manajemen Penyidikan Kepolisian Republik Indonesia, Peraturan Kepala Kepolisian Negara Republik Indonesia Nomer 16 Tahun 2010 Tentang Tata Cara Pelayanan Informasi Publik Di Lingkungan Kepolisian Negara Republik Indonesia, Peraturan Presiden Republik Indonesia Nomer 192 Tahun 2014 Tentang Badan Pengawasan Keuangan Dan Pembangunan.

Proses POLRI Dalam Melakukan

Penyidikan Penangkapan Tindak Pidana Korupsi yaitu Proses awal mulai pelaporan sampai Penyelidikan, penyidikan dan penangkapan. Berdasarkan hasil wawancara dengan Kanit tipikor dan kasat reskrim, ada tahap dan poin-poin nya yaitu Penerimaan informasi atau Laporan, Penelitian Laporan, Penyelidikan, Administrasi Penyelidikan, Skema Penyelidikan, Administrasi Penyelidikan, Penindakan, Penangkapan dan hal-hal yang perlu di perhatikan Untuk mengetahui unsur memperkaya diri sendiri / orang lain maka perlu adanya penelusuran tentang aliran dana dan Aset/ harta kekayaan yang diperoleh hasil kejahatan, Untuk memanggil kepala daerah/wakil kepala daerah harus sesuai dengan tata cara yang diatur Undang-Undang. Untuk lebih jelasnya bisa baca di bab 2 dan bab 3. Jadi Petugas atau penyelidik/penyidik melakukan proses dengan sesuai aturan-aturan yang ada dan tidak menyalahi aturan proses yang ada, bahkan tidak sampai menentang proses yang sudah berlakuk serta sesuai SOP POLRI.

Kendala Kendala yang dialami Polisi (Penyidik, Kanit Tipikor) yaitu Permintaan auditor ke BPKP (Badan Pengawas Keuangan dan Pembangunan) dan BPK (Badan Pemeriksa Keuangan) hasilnya terlalu lama sehingga kasus nya belum bisa terselesaikan, Dalam Menentukan tersangka itu proses yang panjang dan membutuhkan kerja sama dengan berbagai pihak yaitu Inspektorat daerah, Dalam menentukan tersangka tindak pidana korupsi itu membutuhkan proses serta audit dari berbagai lembaga dengan menentukan kerugian negara, Dalam mencari alat bukti berupa Informasi Tekonologi (IT) harus berkordinasi dengan Lab Forensik di Polda Jatim sehingga waktunya lama berdampak dalam waktu penyidikan, dalam memanggil saksi ahli di persidangan yaitu BPK (Badan Pemeriksa Keuangan) dan BPKP (Badan Pengawas Keuangan dan 
Pembangunan) harus bergantian dan menunggu karena personil di provinsi sedikit. ${ }^{4}$

Kendala dari para petugas (penyelidik, penyidik dan Kanit tipikor) kurangnya personil/pegawai (BPK dan BPKP) di provinsi sehingga mengganggu kinerja dalam bekerja, harus terus menerus berkordinasi dengan lembaga-lembaga terkait yaitu (BPK, BPKP, Inspektorat daerah, DPRD dan kejaksaan) seta berkomunikasi sinergi dengan (lembaga swadaya masyarakat, lembaga anti korupsi, masyarakat) agar terselesaikan masalah korupsi dan membangun kabupaten Nganjuk bebas Korupsi. ${ }^{5}$

Kendala yang lain adalah dalam memanggil kepala atau wakil daerah harus disesuaikan menurut aturan aturan dan tata cara pemanggilan yang sesuai dengan aturanya adalah (Pasal 36 Undang-Undang Republik Indonesia No. 32 Th 2004 dan tata caranya).

Solusi untuk mengatasi kendala-kendala penyelidik dan penyidik dalam memberantas tindak pidana korupsi yaitu apabila meminta audit ke BPKP, BPK dengan menggunakan surat permohonan serta langsung datang kantor untuk menanyakan proses nya audit, sehingga proses audit jelas dan tranparan prosesnya, apabila BPKP dan BPK tetep lama proses auditnya bisa meminta bantuan Inspektorat daerah untuk membantu audit kasusnya.

Komunikasi dan bekerja sama untuk bersinergis dalam memberantas tindak pidana korupsi harus tetep terja pada semua instansi atau dengan semua lini sampai ke masyarakat. Seperti Badan Pengawasan Keuangan dan Pembangunan, Badan Pemeriksa Keuangan, Kejaksaan Negeri, Inspektorat Daerah, DPRD, Lembaga Swadaya Masyarakat, Organisasi anti Korupsi, Badan Keuangan Daerah, advokat, Mahasiswa, Tentara Nasional Indonesia dan Masyarakat.

\section{DAFTAR PUSTAKA}

Droharto. Usaha Memahami Undang-undang tentang Peradilan Tata Usaha Negara. Jakarta: Pustaka Harapan. 1993.

KANSIL. CST, Pengantar Ilmu Hukum dan Tata Hukum Indonesia. Jakarta : Balai Pustaka. 1989

\footnotetext{
${ }^{4}$ Wawancara dengan Kepala Unit tipikor Polres Nganjuk,

7 Desember 2017

${ }^{5}$ Wawancara dengan Kasat Satreskrim Polres Nganjuk, 8 Desember 2017
}

Karjadi \& soesilo, Kitab Undang-Undang Hukum Acara Pidana (nomer 8 tabun 1981). Bogor: PT Karya nusantara. 1986

Moleong, Lexy J. Metode Penelitian Kualitatif. Bandung. PT Remaja Indonesia. 2010

Mahmud peter. Penelitian Hukum. Surabaya. Penerbit Prenada Media Grup. 2005

Ridwan HR. Hukum Administrasi Negara. PT Raja Grafindo Persada. Jakarta 2013.

Soesilo R, Kitab Undang-Undang Hukum Pidana. Bogor: PT Karya nusantara. 1986

Sugiyono. Metode Penelitian Kuantitatif, Kualitatif dan ReOD. Bandung. Penerbit Alfabeta. 2011

Tim Penyusun Kamus Pusat Pembinaan dan Pengemban Bahasa, Kamus besar bahasa Indonesia. Jakarta: Departemen Pendidikan Dan Kebudayaan. 1988.

Undang-Undang Dasar Negara Republik Indonesia Tahun 1945 Sesudah Amandemen.

Undang-Undang Republik Indonesia Nomer 15 tahun 2006 Tentang Badan Pemeriksa Keuangan

Undang-Undang Republik Indonesia Nomor 2 Tahun 2002 Tentang Kepolisian Republik. Indonesia.

Undang-Undang Republik Indonesia Nomor 30 Tahun 2002 Komisi Pemberantasan Korupsi

Undang-Undang Republik Indonesia Nomor 28 Tahun 1999 Penyelenggaraan Negara Yang Bersib Dan Bebas Dari Korupsi, Kolusi Dan Nepotisme.

Undang-Undang Republik Indonesia Nomor 31 Tahun 1999 Pemberantasan Tindak Pidana Korupsi

Undang-Undang Republik Indonesia Nomor 36 Tahun 1999 Telekomunikasi

Undang-Undang Republik Indonesia Nomor 20 Tahun 2001 Pemberantasan Tindak Pidana Korupsi

Peraturan Presiden Republik Indonesia Nomer 192 Tahun 2014 Tentang Badan Pengawasan Keuangan Dan Pembangunan

Peraturan Pemerintah Negara Republik Indonesia Nomer 18 Tahun 2016 Tentang Perangkat Daerah

Peraturan Pemerintah Negara Republik Indonesia Nomer 52 Tahun 2000 Tentang Penyelenggaraan Telekomunikasi

Peraturan Pemerintah Negara Republik Indonesia Nomer 71 Tahun 2000 Tentang Tata Cara Pelaksanaan Peran Serta Masyarakat Dan Pemberian Penghargaan 
Dalam Pencegaban Dan Pemberantasan Tindak Pidana Korupsi.

Peraturan Kepala Kepolisian Negara Republik Indonesia Nomer 14 Tahun 2011 Tentang Kode Etik Profesi Kepolisian Republik Indonesia.

Peraturan Kepala Kepolisian Negara Republik Indonesia Nomer 14 Tahun 2012 Tentang Manajemen Penyidikan Kepolisian Republik Indonesia.

Peraturan Kepala Kepolisian Negara Republik Indonesia Nomer 16 Tahun 2010 Tentang Tata Cara Pelayanan Informasi Publik Di Lingkungan Kepolisian Negara Republik Indonesia.

Internet, www.beritatransparansi.com. Litigasi dan non Litigasi 4 September 2017

Internet,http://www.polri.go.id/organisasi/op/ sp, sejarah polri 25 September 2017 